\title{
The freezing point of raw and heat treated sheep milk and its variation during lactation
}

\author{
Bohumíra Janštová, Pavlína Navrátilová, Michaela Králová, Lenka Vorlová \\ University of Veterinary and Pharmaceutical Sciences, Faculty of Veterinary Hygiene and Ecology, \\ Department of Milk Hygiene and Technology, Brno, Czech Republic
}

Received August 1, 2012

Accepted April 23, 2013

\begin{abstract}
The freezing point of milk is an important indicator of the adulteration of the milk with water, but heat treatment may also affect its value. The aim of this study was determine freezing point of raw and heat treated sheep milk and its variation during lactation. The freezing point was determined in 42 bulk tank raw sheep milk samples and 42 pasteurized milk samples collected during lactation of sheep at one ecofarm in Moravian Walachia (Valašsko in the Czech Republic). The freezing point was determined in accordance with the standard ČSN 570538 using a thermistor cryoscope. The average freezing point of raw milk was $-0.617 \pm 0.052{ }^{\circ} \mathrm{C}$, with a range from -0.560 to $-0.875{ }^{\circ} \mathrm{C}$. The freezing point was lower in the first months of lactation and increased at the end of lactation. The freezing point correlated $(r=0.8967)$ with the content of total non-fat solids. The average freezing point of sheep milk pasteurized at $65{ }^{\circ} \mathrm{C}$ for 30 min was $-0.614 \pm 0.053{ }^{\circ} \mathrm{C}$, with a range from -0.564 to $-0.702{ }^{\circ} \mathrm{C}$. The median of freezing point differences between raw and pasteurized milk was $0.004^{\circ} \mathrm{C}$. Our study extends data about physico-chemical properties of sheep milk and registers for the first time specific changes in the freezing point value of sheep milk by heating.
\end{abstract}

Cryoscopy, physico-chemical properties, pasteurization

Information on the composition and features of sheep milk is crucial to the production of high quality sheep dairy products and to cheese production in particular (Bencini 2002). Sheep milk has a higher content of solids than goat and cow milk but, on the other hand, it has a lower freezing point (Park et al. 2007). The milk composition and features vary with the stage of lactation, nutrition, breed, and animal health status (Park et al. 2007; Kuchtík et al. 2008). Freezing point (FP) is an important feature of milk. Of the milk constituents, lactose and chlorides, i.e. substances that form solution in milk, are the major contributors to FP (Fox and McSweeney 1998). Their contents fluctuate depending on, beside the factors mentioned above, the water intake, heat stress, season and $\mathrm{CO}_{2}$ content in milk (Rohm et al. 1991; Antunac et al. 2001; Slaghuis 2001). The effect of protein content is not important, although some authors mention it (Macek et al. 2008), and milk adulteration with extraneous water, added either intentionally or accidentally (Zee et al. 1982; Buchberger 1996). The freezing point of raw sheep milk is lower than those of cow and goat milk (Maurer and Schaeren 2007) because of the higher solids and non-fat solids contents in sheep milk. The average reported sheep milk FP is $-0.570{ }^{\circ} \mathrm{C}$ (Park et al. 2007). Freezing point value of heat-treated milk is dependent on the value of FP of raw milk and the temperature of heat treatment, which causes an increase in FP in the range from 0.001 to $0.009{ }^{\circ} \mathrm{C}$ as observed by Kessler (1984) and Singhal et al. (1997). Rohm et al. (1991) have reported a freezing point about $0.002{ }^{\circ} \mathrm{C}$ depending on the temperature and heating time: the increase is a result of the changes in the calcium phosphate complex and carbon dioxide pressure.

The aim of this study was to determine freezing points of raw and pasteurized sheep milk and their variation during lactation and to assess the effect of pasteurization on freezing points.

Address for correspondence:

Doc. Bohumíra Janštová, MVDr. Ph.D.

Department of Milk Hygiene and Technology

Faculty of Veterinary Hygiene and Ecology, University of Veterinary Sciences

Palackého tř. 1-3, 61242 Brno, Czech Republic
Phone: +420 541712

Fax +420 541711

E-mail: janstovab@vfu.cz

http://actavet.vfu.cz/ 


\section{Materials and Methods}

Raw and pasteurized sheep milk samples were collected on an ecofarm in Moravian Walachia in the Czech Republic. About 100 ewes of Lacaune cross breed, East Friesian and Improved Walachian sheep are bred on this farm. Raw sheep milk was sampled twice monthly from May to November 2011. Unpreserved milk samples were transported in an insulated cool box at $6^{\circ} \mathrm{C}$. In total, 42 samples of raw sheep milk ( 3 per month) and 42 samples of the same sheep milk after pasteurization ( 3 per month) were collected. Milk was pasteurized at $63{ }^{\circ} \mathrm{C}$ for 30 min on the farm.

The average composition (in \%) of raw milk was the following: protein $6.73 \pm 1.689$, fat $8.68 \pm 2.046$, lactose $4.58 \pm 0.715$, solids $20.31 \pm 3.393$ and non-fat solids $12.06 \pm 1.002$. The average composition (in \%) of pasteurized milk was the following: protein $6.82 \pm 1.109$, fat $8.71 \pm 2.024$, lactose $4.62 \pm 0.612$, solids $20.53 \pm 3.343$, and nonfat solids (NFS) $12.18 \pm 1.131$. The milk composition was determined in raw and pasteurised milk in accordance with the standard CSN 570536 (1999) using a Bentley 2500 infrared analyzer (Bentley Instruments, Minnesota, USA) in the laboratory for milk analysis, Brno.

The freezing point of milk was determined in accordance with the standard ČSN 570538 (1998) "Determination of freezing point of milk by the cryoscopic method using" a Funke Gerber Cryostar Automatic 7160 (Funke Gerber, Germany). The thermistor cryoscope was calibrated on a regular basis using standard solutions FB $-0.408^{\circ} \mathrm{C}$ and $-0.600^{\circ} \mathrm{C}$, and Lactrol reference solution $\left(-0.512{ }^{\circ} \mathrm{C}\right)$.

The measurement uncertainty was $0.61 \%$ : it is a combined uncertainty at a confidence level $U=95 \%$ for a coverage factor $\mathrm{k}=2$, which indicates approximately $95 \%$ confidence level. Basic statistical analyses were performed using Unistat 5.1 software - the significance of differences $P$ and median differences between FP raw and pasteurized milk (Unistat Ltd. 1998).

\section{Results}

The monthly average FP values of raw sheep milk during the study period varied from $-0.584{ }^{\circ} \mathrm{C}$ to $-0.724{ }^{\circ} \mathrm{C}$ and the average FP for the whole study period was $-0.617{ }^{\circ} \mathrm{C} \pm$ $0.052{ }^{\circ} \mathrm{C}$ (Table 1$)$.

At the beginning of the study period (month 5), the average FP was $-0.584 \pm 0.010{ }^{\circ} \mathrm{C}$ while in the summer (month 8), it decreased to $-0.625^{\circ} \mathrm{C}$. At the end of lactation (month 10), FP decreased to $-0.637^{\circ} \mathrm{C}$. Grazing season ended at the beginning of November (month 11). In those last days of lactation a significant decrease of $\mathrm{FP}\left(-0.724^{\circ} \mathrm{C}\right)$ was recorded as a result of reduced milk production, which corresponded to the increased dry matter content. The average NFS content of raw sheep milk was $12.06 \pm 1.002 \%$, ranging from 11.20 to $13.69 \%$. Freezing point correlated $(\mathrm{r}=0.8967)$ with the non-fat solids content $(P=0.05)$.

Table 1. Average freezing points of raw sheep milk during the study period $\left({ }^{\circ} \mathrm{C}\right)$.

\begin{tabular}{|c|c|c|c|c|c|c|c|c|}
\hline $\begin{array}{l}\text { Statistical } \\
\text { evaluation }\end{array}$ & $\begin{array}{l}\text { Month* } \\
5\end{array}$ & 6 & 7 & 8 & 9 & 10 & 11 & $\begin{array}{l}\text { Whole study } \\
\text { period }\end{array}$ \\
\hline $\bar{x}$ & -0.584 & -0.594 & -0.572 & -0.625 & -0.586 & -0.637 & -0.724 & -0.617 \\
\hline SD & 0.006 & 0.026 & 0.011 & 0.025 & 0.006 & 0.021 & 0.108 & 0.052 \\
\hline $\min$ & -0.588 & -0.619 & -0.582 & -0.672 & -0.579 & -0.669 & -0.875 & -0.875 \\
\hline $\max$ & -0.579 & -0.560 & -0.560 & -0.578 & -0.588 & -0.565 & -0.573 & -0.560 \\
\hline
\end{tabular}

$\bar{x}$ - average, SD - standard deviation, min - minimum, max - maximum, *May-November

Table 2. Average freezing points of pasteurized sheep milk during study period $\left({ }^{\circ} \mathrm{C}\right)$.

\begin{tabular}{lcccccccc}
\hline $\begin{array}{l}\text { Statistical } \\
\text { evaluation }\end{array}$ & $\begin{array}{c}\text { Month* } \\
5\end{array}$ & 6 & 7 & 8 & 9 & \multicolumn{1}{c}{10} & \multicolumn{2}{c}{$\begin{array}{c}\text { Whole study } \\
\text { period }\end{array}$} \\
\hline $\bar{x}$ & -0.581 & -0.591 & -0.568 & -0.622 & -0.571 & -0.622 & -0.720 & -0.614 \\
SD & 0.014 & 0.013 & 0.007 & 0.020 & 0.006 & 0.018 & 0.048 & 0.053 \\
$\min$ & -0.574 & -0.577 & -0.567 & -0.624 & -0.580 & -0.625 & -0.702 & -0.702 \\
$\max$ & -0.564 & -0.564 & -0.564 & -0.592 & -0.565 & -0.591 & -0.665 & -0.564 \\
\hline
\end{tabular}

$\bar{x}$ - average, SD - standard deviation, min - minimum, max - maximum, *May-November 
Table 2 displays the FP values determined in sheep milk pasteurized at $63{ }^{\circ} \mathrm{C}$ for $30 \mathrm{~min}$ which corresponds to pasteurization at $72{ }^{\circ} \mathrm{C}$ for $15 \mathrm{~s}$ (Regulation EC No 853/2004).

The average FP of pasteurized sheep milk per study period was $-0.614{ }^{\circ} \mathrm{C} \pm 0.053{ }^{\circ} \mathrm{C}$ and the average monthly FP ranged from $-0.564^{\circ} \mathrm{C}$ to $-0.720{ }^{\circ} \mathrm{C}$. The average NFS content of pasteurized sheep milk was $12.18 \pm 1.131 \%$ and was by $0.01 \%$ higher than the NFS content of raw sheep milk, but the difference was not significant $(P>0.05)$.

The dynamics of FP changes in pasteurized milk during the lactation period follow the pattern of those in raw sheep milk. The differences between FPs of raw and pasteurized sheep milk determined by paired $t$ test were highly significant $(P=0.01)$. After pasteurization, the average FP increased by $0.004{ }^{\circ} \mathrm{C}$ compared to raw milk (median of differences between FP raw and pasteurized milk).

\section{Discussion}

No literature data on the FP variation in sheep milk induced by heat treatment have been available, but from the above mentioned results it follows that the dynamics of the FP variation in the pasteurized sheep milk should follow the patterns observed for the pasteurized cow and goat milk.

The average FP of raw sheep for every month and for the whole study period corresponded to the findings of other authors. The following freezing points were found: $-0.564{ }^{\circ} \mathrm{C}$ to $-0.570{ }^{\circ} \mathrm{C}$ (Pavić et al. 2002), $-0.568{ }^{\circ} \mathrm{C}$ (Petrova and Nedelchev 2002), $-0.570{ }^{\circ} \mathrm{C}$ (Park et al. 2007), $-0.6048^{\circ} \mathrm{C}$ (Macek et al. 2008) and $-0.560{ }^{\circ} \mathrm{C}$ to $-0.610{ }^{\circ} \mathrm{C}$ (Kerestes 2008).

The different results document seasonal variation of FP of raw sheep milk depending on the stage of lactation, climate change and nutrition. The average value of FP in our study decreased in the summer, most probably as a result of high temperatures in the surrounding environment and short-term dehydration of the animals, as also reported by Bjerg et al. (2005). Early in month 11 when the grazing season ended with reduced milk production, FP value was the lowest, corresponding to a higher content of solids also reported by Kuchtík et al. (2008). Nevertheless, this minimal FP markedly influenced the average FP during lactation, and therefore, the average FP in our study is lower than reported by others (Pavić et al. 2002; Petrova and Nedelchev 2002; Park et al. 2007; Macek et al. 2008; Keresteš 2008). Nevertheless, the average FP of $-0.601{ }^{\circ} \mathrm{C}$ calculated for the period of mature milk production (months 5 to 10 ) is consistent with their data. In practice, the determination of milk FP is helpful primarily in detecting milk adulteration with water (Bhandari and Singh 2003). For instance in Bulgaria, the limit of $-0.585^{\circ} \mathrm{C}$ was set for FP of sheep milk (Keresteš 2008).

Significantly higher contents of NFS raw sheep milk were found, clearly exceeding the $9.5 \%$ required by the standard STN $570510 / 1993$ and the $11.45 \%$ reported by Pavić et al. (2002).

As the determined NFS content is not suggestive of milk adulteration with water, the increased FP seems to be a result of milk changes after heat processing, as reported by Rohm et al. (1991).

Kessler (1984) has found that FP of cow's milk remains the same after pasteurization at $74{ }^{\circ} \mathrm{C}$ for $30 \mathrm{~s}$ but increases by $0.002{ }^{\circ} \mathrm{C}$ after high pasteurization at $85{ }^{\circ} \mathrm{C}$ for $2.8 \mathrm{~s}$. Other authors have found the heat treatment to have a more substantial impact on FP of milk: FP increases by 0.006 to $0.009{ }^{\circ} \mathrm{C}$ after pasteurization and by $0.023{ }^{\circ} \mathrm{C}$ after ultra high temperature (UHT) treatment as reported by Singhal et al. (1997). Anyway, the effect observed, i.e. increase in FP of pasteurized milk, is a result of milk protein response to the heat shock (Rohm et al. 1991), and, at the same time, of water removal from milk by evaporation, with the milk becoming thicker. Janštová et al. (2009) found FPs of cow and 
goat milk to increase by $0.0023^{\circ} \mathrm{C}$ and $0.0028^{\circ} \mathrm{C}$, respectively, as a result of pasteurization at $72{ }^{\circ} \mathrm{C}$ for $20 \mathrm{~s}$ in comparison with raw milk; a lower FP of sheep milk (by $0.003{ }^{\circ} \mathrm{C}$ ) was expected, given the higher NFS content and lower FP of raw milk.

\section{Acknowledgement}

This study was supported by Grant MSM 6215712402 of the Ministry of Education, Youth and Sports of the Czech Republic.

\section{References}

Antunac N, Havranek J, Samarzija D 2001: Freezing point of goat milk. Milchwissenschaft 56: 14-16.

Bencini R 2002: Factors affecting the clotting properties of sheep milk. J Sci Food Agric 82: 705-719

Bhandari V, Singh H 2003: Physical methods. In: Roginski H. (ed.): Encyclopedia of Dairy Sciences. Vol. I. Academic Press, London. pp. 93-101

Bjerg M, Rasmussen MD, Nielsen MO 2005: Changes of freezing point of blood and milk during dehydratation and rehydratation in lactating cows. J Dairy Sci 8: 3174-3185

Buchberger J 1996: Some comments on the milk freezing point (in Czech). Cattle Research 4: 23-25

ČSN 570536 1999: Determination of milk composition by mid-infrared analyzer. Prague. Czech Standardization Institute, $12 \mathrm{p}$.

ČSN 570538 1998: Determination of freezing point in milk - cryoscope method. Prague. Czech Standardization Institute, $6 \mathrm{p}$.

Fox PF, McSweeney PLH 1998: Dairy chemistry and biochemistry. Thomson Science, London. pp. 443-447

Park YW, Juarez M, Ramos M, Haenlein GFW 2007: Sheep milk- production and utilization of sheep milk. Small Rumin Res 68: $88-113$

Janštová B, Navrátilová P, Dračková M, Přidalová H, Vorlová L 2009: Impact of heat treatment on

the freezing points of cow and goat milk. Acta Vet Brno 4: 679-684

Kessler HG 1984: Effects of the technological processes on the freezing point of milk. Milchwissenschaft 39: $339-341$

Keresteš J 2008: Sheep breeding in Slovakia - history and technologies (In Slovak). $1^{\text {st }}$ edition, Nika, Ltd. Považská Bystrica: Eminent, Slovakia, 592 p.

Kuchtík J, Šustová K, Urban T, Zapletal D 2008: Effect of the stage of lactation on milk composition, its properties and the quality of rennet curling in East Friesian ewes. Czech J Anim Sci 53: 55-63

Macek A., Hanuš O, Genčurová V, Vyletělová M, Kopecká J 2008: The relation of sheep's and cow's freezing point of milk to its composition and properties. Scientia Agric Bohem 39: 329-334

Maurer J, Schaeren W 2007: Sheep milk is a high -value food. Agrarforschung 14: 156-161

Pavić V, Antunac N, Mioč B, Ivankovič A, Havranek L 2002: Influence of stage of lactation on the chemical composition and physical properties of sheep milk. Czech J Anim Sci 47: 80-84

Park YW, Juarez M, Ramos M, Haenlein GFW 2007: Physico-chemical characteristics of goat and sheep milk. Small Rumin Res 68: 88-113

Petrova N and Nedelchev D 2002: Production, composition and some properties of sheep milk from East Friesian $\mathrm{x} 1 / 4$ East Friesian x Awassi dairy population. Bulg J Agric Sci 8: 295-300

Regulation (EC) No 853/2004 of the European Parliament and of the Council of 29 April 2004 laying down specific hygiene rules for food of animal origin. Official Journal of the European Union, 2004, No. L. 139: 14-74

Rohm H, Pleschberger C, Foissy H 1991: The freezing point of austrian raw milk. 1.The factors influencing the original freezing point (in German). Ernährung 15: 333-337

Singhal RS, Kulkarni PR, Rege DV 1997: Handbook of indices of food quality and authenticity. Woodhead Publishing Limited, Cambridge England, pp. 168-174

Slaghuis BA 2001: The freezing point of authentic and original farm bulk tank milk in the Netherlands. Int Dairy J 11: $121-126$

STN 570510 1993: Sheep milk (in Slovak). Slovak Institute of Technical Standardization. Bratislava, 4 p.

Zee B, Drogt J, Giessen TJJ 1982: The freezing point of authentic farm tank milk in the Netherlands. Neth Milk Dairy J 36: 291-303 